in froat. The murmur mas bo dull and mufiled, requiring the pressure of the rtethoecope to elicit its distinet character. It it limited tranoversoly to the seat of the disense, and mopareted more extensivel below than above that spot, and where sometimes it is alone audible. Dr. Walshe mentions, and this I have also had an opportunity of rerifing, that in somo instances systolic murmur is audible in the reclining, when inaudible in the erect posture; and again, a alreads stated, that in other cases no murmur whatever can be detected in any posture. Lastly, the aneurismal sound is insudible over the heart.

The general symptoms of ventral aortic aneurism, when taken per $*$, are extremely vague and perplexing. The reasel, in its passage through the abdomen, being closely embraced by filaments from the solar plexus and other nerres, the neuralgic sufferings are often very intense.

The seat of the pain, often intermittent in character, is of course influenced by the locality of the sac; it is especially severe in the loins, lancinating upwrards and in front to the hypochondriac and abdominal regions, and below, to the testicles and lower extremities, which may become contracted and eonvulsed. The pain often assumes the character of colie, and the poor patient describes his sufferings in the most graphic terms. The pulse is not often materially affected, and the appetite may continue moderately good. Pressure on the intestines may interfere with the functions of these viscers; and if the sac be large and seated high up in the abdomen, it may, by impeding phrenic action, render the respiration accelerated, and give rise to severe pulmonary distress. Such are the leading features, physical and general, which more or less obtain to aneurism of the abdominal aorta.

We may now briefly consider those other affections by which this is occasionally simulated, and which become both important and interesting in reference to its differential dingmosis. The first which we may notice, and which sometimes closely resembles ventral aneurism, is simple aortic pulsation from functional disturbance. This latter, occurring in dyspeptic and anæmic subjects, will be recognised by its concomitant nerrous or anæmic symptoms.

In aneurism, as we have seen, the pain is something truly aronising; in simpie aortic pulsation, this symptom is absent. The functional disorder is further diagnosed by its aggravation on slight exciting causes, and by its want of permanency; again, the sound and impulse are short, abrupt, and jerking, in contradistinction to the slow, heaving, expansive pulsation of aneurism, nor is the impulse so decidedly confined to a particular portion of the artery.

Inorganic pulsation may be attended with a systolic cound, but this, as a rule, is inaudible in the back. It is not unfrequently accompanied by a coexisting murmur in the neck. Iastly, the sex of the patient will assist our aiagnosis; for while abdominal aneurism in the female is of very rare occurrence, inorganic aortic pulsation is very common. Freal accumulation and impaction has been mistaken for aneurism of the abdominal aorta. The oval hape of the tumour, with its doughy, inelastic feel, and the result of free purgation, will in general suffice to clear up the diagnosis. Enlarged glands, or organic disease of the abdominal viscera, either lying over, or pressing laterally upon the artery, will sometimes closely simulate aneurism. The history of the case, and especially the existence of malignant disease in other parts of the body, will aid our opinion; while in pulsation from superimposed tumour, the murmur may often be interrupted by change of position, or by applying the stethoscope laterally and displacing the tumour from off the artery. The obscurity of the symptoms, and pain accompanying lumbar and psoas abscess, may resemble the phenomens of aneurism, but the swelling, dongating downwards, without sound or impulse, and the want of the globular tumour of the enlarged artery, will in goneral distinguish these affections.

Tumours of the kidney mas, by extending irregularly inwands and receiving the shock of the artery, sometimes recemble an aneurismal swelling; but the condition of the wine and the previous history of the case will sufficiently assist the dingnosis. It should be borne in mind, howerer, that an anourism pressing upon the emulgent rein may render the urine albuminous.

In all cases in which the symptoms are obscure (and in rery many they will inevitably prove at first to be so), it will be well to examine the patient both in the erect, horizontal, and lateral postures, and in some instances it may be prudent to watch the case for a time before hazarding the responsibility of a positive opinion.

Ipswich, June 1854.

\section{NEUROMA OF THE LEFT MEDIAN NERVE.}

By W. E. IMAGE, Esq., Surgeon to the Suffolk General Hospital.

[Read at the Annual Meeting of the Suffolk Branch, June 23rd, 1854.]

MART Jobsor, aged 29, a married woman, was admitted into the Suffolk General Hospital on October 4th, 1853. She had enjoyed good health up to the 8th of November, 1850; never having experienced pain or any other inconvenience in the arm or hand. The first intimation of disease was sudden: she was roused from her sleep by a violent pain in the palm of the hand, just below the thumb. This occurred on the night of the 8th, at one o'clock. The acute pain continued for four hours; it then remitted, but never wholly ceased. At one o'clock the following day, a severe exacerbation occurred. In the following night, the paroxysm recurred; and, from that time to the period of her admission into the hospital, the disease wore this very decidedly paroxysmal character. The paroxysms were regular, both as to the time of their access and duration. They occurred regularly at one o'clock, night and day; and continued for four hours. The pain in the hand never ceased, from the first attack up to the day of the operation; it only remitted. $\Lambda$ "darting and aching" pain, to use her own expression, always continued in the palm of her hand.

Six months after the first attack, she accidentally discovered a small tumour, of the size of a pea, about three inches above the inner condyle. She became aware of it, by a person grasping her arm. She paid but little heed to this small tumour, as she had no reason to refer her suffering in her hand to this part; as it was only, for the present, painful when touched. The tumour continued in this state for six months after this time, or twelve months from the commencement of the pain in the hand, before she experienced any pain in it, except when pressed; but not then communicating pain to a distance.

In Norember 1851 , the tumour began to be painful, eren when no pressure was applied to it. The pain extended up to the shoulder, side of the neck, and half the head; and when the tumour voas touched, the pain was " sent" (her own word) to the palm of the hand, but not in the upward direction. The tumour slowly increased in size; the pain in the part greatly increased; the paroxysmal character continued; and, when she arrived at the hospital, she was worn down by suffering and sleepless nights. No treatment gave any real relief; indeed, it sometimes appeared to aggravate her suffering. Blisters alone appeared to afford any alleviation. They also completely failed. The tumour was moveable in a transverse direction, but not in the axis of the nerve.

Oct. 31st. I remored the tumour, with half an inch of the median nerve attached at each end. The disease was not adherent to the surrounding tissues. All pain ceased in the arm and hand. The thumb and middle fingers were numb and powerless. She could not close the hand; she could just move the fingers, and had some sensation in them, but it was very deficient. The little finger was quite normal; the ring finger partially so. The wound progressed favourably; her health began to improve; her sleep returned; and she left the hospital cured.

I had an opportunity of seeing her in April 1854. Her health was restored; sho had never had any pain since she left; the renation in the hand was restored; and the power 
of elocing ber hand also almont secorrened. I cheerved thet the wot shle to eloce the lent hand quite co firmly as the right.

Prinere. This case is interesting in a practical point of viow, as it shows the uselesenese of any known plan of trentroent; and also that so important a nerve as the rodinn may be cut through, without any very. serious injery to the future usefulmess of the limb.

Bury St. Edmund's, Jans $185 t$.

\section{PIRISCOPIC REVINW.}

\section{IPIDIDOLOAY, HYGDAICS, AND STATISTICS.}

\section{REPORT ON THE RECENT PROGRESS OF CHOLERA.}

Part I. By John Chatto, Ese.

TrE epidemic which during the last year or two has been committing devastations in various parts of Europe seems to have arisen in Persia, in the years 1851-2, and prevailed there to a fearful extent. M. ERsest CLOQUET, at that time a resident at Tetreran, in the accounts he sent to the French Acidemy of Medicine, states that it first declared itself at Basserah in 1851, followed the course of the Tigris so to reach Bagdad in 1852, and then traversing Burdistan, opread into Azerbijan. After ravegiag this province, and especially its capital, Tauris (where, eocording to some aocounte, probably much eraggerated, 1000 persons died daily), its course was directed to the sonth and gouth east, along the borders of the Caspian Sea. Teheran in this way became the seat of cholera at the beginning of April 1853, the disease reaching it, contrary to all precedent, from the north. The temperature of this spring waS remarkably low, the wind blowing from the N.E. and S.E., and the air being lorded with moisture. During April, May, and the hal of Jume, at least forty-five persons were carried of per diem in a population reduced by flight to thirty or forty thonsand. By the beginning of August, it had nearly cessed Teherren, though still prevailing with great severity in otber parts of Persia eepecially in the eastern and soutbern provinces. It is calculated that, of a pepulation of 160,000 souls, comprised in Tebaren and its environs, from 15,000 to 16,000 perished. At the same time, the epidemic prevailed, though with less intensity, at Emmenah, placed at 7000 foet ahove the level of the sea: the weather, too, being so cold that snow fell in May.

The outbreak of cholera in Poland in 1852 was, according to Dr. Tecretrararn, President of the Sanitary Commission, unprecedented in the sudden and spontaneous character of its aperrance. No cases had been met with in that country since the end of 1851, when the disease snddenly appeared in the district of Boeradz, in the government of Warsaw, on May 24th, 1852, and eread thence in every direction. It did so, however, in the mest irregular manner, sometimes collcentrating itself in certain localities, and then spreading by leaps to distant populations, leaving intermediate places for the time nnscathed. The first cases occurring at Warsaw appeared in separate parts of the city, and were not traceable to intercommunication. To the 5 th of September, the number of cases amounted to 10,673 , of which 4,4f2 died, 5,908 recovered, and 303 remained under treatment. The culminating point of the epidemic was the thirty-fourth dey, the 10th of August, when 370 new eases occurred. The total number of cases occurring in the government of Warsaw to the 5th of September amounted to $49, \mathbf{3 2 8}$, of which 20,906 died, 20,153 recovered, and 4,710 remained under treatment; this being indeed the most disestrous epidemic of this disease ever witnessod in Poland. Notwithstending the large ormies stationed in this provinee, they furnished only 2,066 cases; the observance of hygienic laws having been most rigidly insisted on.

M. ANEDEE LATOUR, examining the history of the progress of this Polish epidemic, regards it as differing from other recorded igitations of the disease; for, althongh cholers had been raging in Persia, and around the Persian Gulf, it never advenced thenoe to the Russien extem frontier. He thinks it beens moeve analosy to some of the epreat epidenics due to the boed prevalence of peculiar "epidemical constitations", wach as those obeerved in Iondon by Willis and Sydenham, in 1670 and 1676.

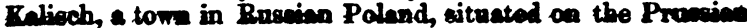

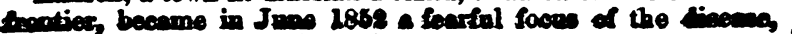

foritives trangporting it bence in July to the Prassian tom Ostrow and Ptesolien, in the Dechy of Pvocen. of

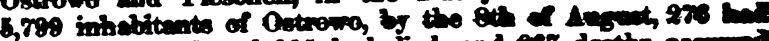

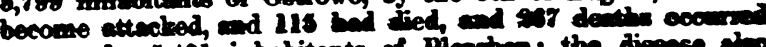

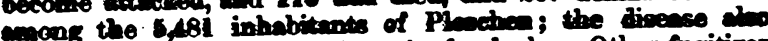
rupidly spreading to other pleow in the dacks. Other fopitive

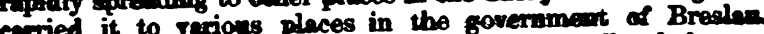
Breslax bod indoed, not long priox to this, suffered from a Breslax bad indoed, not long priox to this, sureared from 1851, to Jenuary 8th, 1852, furnishing 345 cases and 271 deathe in a population of 167,507 . The epidemic seems on that occain accounts in the Prussian Medicinische Zitung, to have travelled from Bohemia, where 58,121 indiviZeitung, to have travelled are stated to have been attached during 1851, of this number 23,225 dying.

At a not mach leter date than that of the immigration of the disease by $\mathbf{K}$ alisch, it traversed the fromtiers of Eastera and Westem Prussian at other points, it beieg bromght to several pleces spparenth by reftsmen flowing timbor trom Galicis and places apparenthy by the 20th of A ugust, 153 cases, furnishing 80 deaths, had oceurred in the town of Dantric, and by the 19th of September these numbers had increased to 1,161 and 674 re September these numbers haring in the entire government of spectively. The cases occurring in the ent the deaths 4,572 . the same name were 7,541 in number, and the deaths 4,572 Later still, Berlin and Landsberg were attacked, 235 cases and 152 deaths occurring in the former vity, and 308 cases with 194 1eaths taking place in the latter. Many other places swifered in the prenimes of Brandenburg and Silesia, and nome of these the provinees of Brindenters government fumistred to the severefy. The Marienwerden goveniment 5,640 deaths. Amow middle of Nowember 9 , Pesen, 2,571 esses and 1,856 deathe the 42,186 inhabitints ; while, in the entire goremment of that name, there ceours ; 17ile, is the with 11,292 deaths.

Dr. Laventhat (Medic.-Zeitung, July 1853) gives a fer interesting details of the outbreak of the epidemic at Prenzlau, place of 12,720 inhabitants. No epidemic had occurred for a place of 12, rery long period, and the public health Howner this may be posed to be in a very satisfactory state. Howner this mats bo as regards some of the more marked tiseases, as a mortaity of 30 to 82 per 1,000 oocurred, there was evidently not much to bengt of for a provincial town. The locality is singralarily froe from coses of pulmonery consumption, while typhoid and inter mittent fevers, together with rheumetic and caterrhal affections mittent fevers, together with rheum a lat district, unsheltered by are prevalent; the town lying in a fat district, uns croup are mountains from the north wind. Pneumosia and croup are also of frequent occurrence. Sume cases of sporadic diarrhce occurred in the sutumn of 1852 ; bat the affection had scquired less extension than in some other years, when a chimney-sweep arriving from Bertin exhibited symptoms of cholern on the ird arriving from Berlin extiest subsequent cases were believed to of October, and the eartiest subsequent cases were believed thbe traceable to his residence. The epidemic reached its maximum by the fourth week, and then graduslly cooreceed. From mum by the fourth week, and 23 d of December, 1,662 persons (761 males and 808 females) were attrecked, and of these 622 (274 males and 848 females) died. Jews reem to have enjoyed marked exemption from the diseese.

Thed exersis in 1853, cos The epidemic of chen observed in former invasions, which trary to what has boen Russ-Polish, Austrian, or Bohemian hove taken place by the Russo-Polish, Austrian, or Boherian frontiens, made its descent at the seaboard, without, howover,
entirely neglecting its old course along the Vistula. Tht entirely indeed, was chiefly spent upon the maritime provinees, attack, indeed, was chiefly spent npon the marrime provincer, few places in Posen or Brandenburg surifested themeel we It is remarkable that the same day (Jahy 18 th) at four widedy distant places, vit. Meene Although the chice remel, Dratsic, Stotin, and Te obeerved, on this occasion, at manifestations of the disease were observed, on cocurred, toward the maritime towns, yet traces of its presenoe frontiers of the the end of Jaly, at pleoes situated on the frontiens of tho commnnicates by the Vistuta with Poland and Galieia, it spread to Kulm and other places, but to no great extent. At Dantzic, to Kulm and other places, but to nolish raftsmen and foreig. the cases chiefly occurred amoug pome of the adjuining towns. sailors, and thence it spread to soco of thed Stettin sinenatod The entire number of cases that To the 21 st of Nopomber, 1,4us 101,156 , of which 710 died. To the $218 t$ this nomer, 418 caces canes had been observed at Bertin. Of this miner, 118 cas

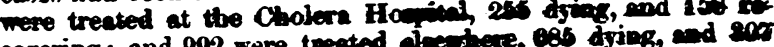

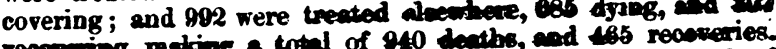

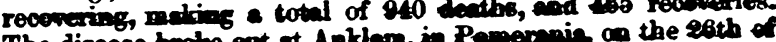

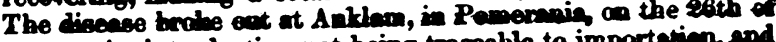
Angest, its intudation not being tracenle to importation, and

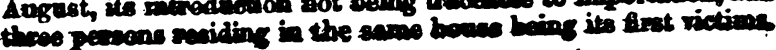

